\title{
Iowa Inherits Squirrel Hunters
}

\author{
By Nell Woods Black
}

Mrs. Black is a retired educator who has served as administrator and classroom teacher in Iowa public schools for 26 years and for 14 years as director of the Westminster Foundation program for Presbyterian students at the college in Cedar Falls where she lives. She was graduated from Iowa State Teachers College in 1926 and received her Master's degree from the State University of Iowa in 1933.

One of the events in the Civil War that is not generally given more than a passing sentence or so in most books on that period of American history is the story of the Squirrel Hunters. Because my father was a Squirrel Hunter, I decided to find out who they were and what they did that made him proud to be one.

My research has taken me from inherited files of letters, clippings and books to the National Archives and finally to the adjutant general's office in the State House at Columbus, Ohio, for I soon discovered that the Squirrel Hunters belong to Ohio history and that their records, incomplete as they are, are housed there.

The Squirrel Hunters were the able-bodied citizens of Ohio who answered the call of Gov. David Tod in September of 1862 when the Confederate forces under Gen. Kirby Smith were taking over in Kentucky and beginning to threaten Cincinnati and other river cities.

Kentucky, a slave state remaining in the Union and trying to maintain a sort of neutrality, posed a real problem for Ohio. When Kentucky refused to furnish its quota of volunteers for the North, Ohio not only filled her own quota, but Kentucky's also. In addition, Ohio had to keep a watchful eye for border raids all along her southern boundary.

According to Lt. Col. William B. Haines, present chief of the division of veteran affairs in the Ohio adjutant general's office in Columbus, "little has been written about these intrepid volunteers who answered Governor Tod's emergency appeal of Sept. 2, 1862, to come to the defense of Cincinnati." That is what the 50,000 to 60,000 citizens of assorted ages and conditions of men who volunteered were called upon to do. 
These men, clad in homespun and armed with weapons of every sort, were organized into companies and put under the command of General Lew Wallace. Martial law was declared. Through hard work and vigilant effort the people of Ohio made ready to defend their river city. Gen. Braxton Bragg, following General Smith into Kentucky, soon learned through his scouts that Cincinnati was preparing a formidable defense of entrenchments and men. He changed his mind at once about further advance and ordered all Confederate forces to withdraw farther south in Kentucky.

Meanwhile Cincinnati was tense, awaiting the attack. After a night of suspense on September 11, General Wallace sent out scouts to find out what the Confederates were doing. They returned to report that the Rebels had fled. Cincinnati was saved. Wallace reviewed the Squirrel Hunters, as the citizen soldiers had been dubbed by an army paymaster, and thanked them for their gallant action in volunteering for the defense of Cincinnati and Ohio. Then he dismissed them to return to their homes. The spirited Ohioans had weathered their crisis.

Many of the Squirrel Hunters did return home, unlisted and unknown; some entered the regular army; 15,766 of them applied for discharges which they received along with a letter of commendation from Governor 'Tod, dated March 4, 1863. It was not until 1908 that Ohio officially recognized the service of the Squirrel Hunters by taking joint legislative action to pay each survivor who could give proof of his having been a Squirrel Hunter a month's militia pay at the time of service$\$ 13$.

The Squirrel Hunters never received the pension or the right to enter the National Soldiers Home at Sandusky, privileges which they were seeking in the early 1900's. Only 2,065 men out of the 50,000 to 60,000 volunteers in September of 1862 received the bonus payment of $\$ 13$, according to Colonel Haines in whose office the paid voucher file is kept.

Twenty-one of the men who received the bonus payment lived in Iowa at the time of this recognition. My father was one of them. He received his bonus check September 20, 1909, nearly 50 years after his service as an Ohio Squirrel Hunter. The entire list, certified from the adjutant general's office in Columbus on September 27, 1960, gives the names of these 
Buckeye Hawkeyes, their Iowa mailing addresses at the time of payment and the Ohio counties of their residence in 1862. The list follows:

Samuel Appleby, Creston, from Preble County in Ohio; O. Bruce, Walnut, Morrow County; William Frazier, Davis City, Knox County; I. N. Gardner, Oakland, Morrow County, Samson Hinds, Lineville, Gallia County; John N. Irwin, Keokuk, no county listed; Perry King, Fairfield, Highland County; Joseph A. McLoskey, Follets, Hamilton County; James McNeal, Vinton, Morrow County; Thomas H. Platter, Persia, Ross County; Thomas Page, Luther, Clinton County.

Crawford Reed, Chelsea, Union County; J. W. Sleetman, Sheldon, Clark County; Robert Shankland, Monroe, Ashtabula County; David Sims, Winterset, Knox County; Theodore F. Shunk, Afton, Morrow County; Henry Underwood, Davis City, Clinton County; John W. Wroten, Des Moines, Clinton County; John Warnock, Washington, Greene County; N. B. Woods, Manson, Defiance County; and William R. Hollingsworth, Burlington, no county listed.

At least one man on the list received all three papers of recognition-a Squirrel Hunter discharge, a letter of commendation from Governor Tod and the bonus payment of $\$ 13$. He was Robert Shankland of Monroe whose son, Frank S. Shankland, wrote a feature article for the Sunday Des Moines Register and Leader of April 24, 1904, in which he told about the patriotic zeal of the Ohio Squirrel Hunters and their success in the defense of Cincinnati. He also gave the texts of both the discharge and the Governor Tod letter. He mentions other Squirrel Hunters in Iowa-Ralph Robinson, editor of the Newton Journal, Samuel McKee of Monroe and a Phil Hall ${ }^{1}$ of Cedar Falls "who died some time during the past winter."

The same newspaper on June 28, 1904, carried a letter to the editor from A. J. Jewell of Oskaloosa who wrote that although the Squirrel Hunters in Iowa were too few in number to effect any organization, he would like to have a reunion and sug-

1 The City Directory of Cedar Falls for 1901-1902 lists Phil C. Hall and his wife Mary as residing at 709 Washington street. The county clerk's office in Waterloo had the record of his death on Dec. 14, 1903, with burial in Fairview cemetery at Cedar Falls. I found his grave and noted that it bore a GAR marker which signifies that he was more than "just a Squirrel Hunter." 
gested the Iowa State Fair in Des Moines as the proper place for such a gathering.

An interesting sidelight on the certified list was the trouble I had in verifying Folletts as a post office. It was a mailing address at the time Mr. McLoskey received his bonus check, but like so many other Iowa post offices of the early 1900's, it has succumbed to the blows of postal reorganization. It is located near Clinton, as the map illustration shows.

The map shows the location of each Squirrel Hunter in Iowa at the time of his bonus payment, and it shows more. After the war between the states ended, the population trek westward tended to cross Iowa in the southern half of the state, a migration corridor during the middle decades of the 19th century.

In a dedication speech given at the new city hall in Xenia, Ohio, on February 16, 1881, Whitelaw Reid, American journalist and diplomat, said "For the past 20 years migration westward has been from Ohio. There is no land into which Ohioans have not gone. There is no state or territory to the westward which Ohio emigrants have not helped to people."

It was inevitable that some of Ohio's Squirrel Hunters would be in that westward population movement; it was also inevitable that some of them, pausing to look at Iowa's fertile soil and rich resources, would choose Iowa as their permanent home. At least 25 of them did-probably more.

As my father always cherished a great pride in having been an Ohio Squirrel Hunter, I have taken pride in being able to tell his story and that of his comrades 100 years later.

\section{BIBLIOGRAPHY}

1. State of Ohio, The Squirrel Hunter Discharge. Sept. 1862.

2. Gov. David Tod, Letter of Commendation to Squirrel Hunters. Sent to each Squirrel Hunter who applied for discharge. Mar. 4, 1863.

3. Thomas Buchanan Read, "The Siege of Cincinnati." Atlantic Monthly, Vol. 11, pp. 229-234. Feb. 1893.

4. Whitelaw, Reid, Ohio in the War. Vol. 1, chap. 8. Moore, Wilstach and Baldwin, Cincinnati. 1868.

5. Samuel S. Cox, Three Decades of Federal Legislation. J. A. and R. A. Reid, Providence, R. I. 1885.

6. N. E. Jones, M.D., The Squirrel Hunters of Ohio. Robert Clark company. 1898.

7. Frank S. Shankland, "Only Three Iowans Survive the Band." Des Moines Register and Leader. Apr. 24, 1904.

8. A. J. Jewell, Oskaloosa, "Letter to the Editor." Des Moines Register and Leader. June 28, 1904. 
9. Charles P. King, "The Important Part the Squirrel Hunters Played in the War of the Rebellion in Ohio." Speech given at the first reunion of the Squirrel Hunters in Ohio. Sept. 12, 1906.

10. Capt. John Crowe, Letter to W. B. Woods, Manson, June 24, 1908.

11. W. B. Woods, Letter of Inquiry to Adjutant General, Columbus, Ohio, Aug. 19, 1911.

12. Daniel J. Ryan, Ohio in Four Wars: a Military History. Heer Press, Columbus, Ohio. 1917.

13. Eugene H. Roseboom, History of the State of Ohio. Vol. 4. Columbus, Ohio, 1944.

14. Irving McKee, Ben-Hur Wallace. University of California Press, Berkley and Los Angeles. 1947.

15. Joseph S. Stern, Jr., "The Siege of Cincinnati." Bulletin of the Historical and Philosophical Society of Ohio. July, 1960.

16. State of Ohio, Department of Soldiers Claims, Certified Photocopy of Voucher Records. In adjutant general's office, Columbus. Sept. 27, 1960.

17. Daniel F. Clancy, "Ohio's Oddest Army." Dispatch Magazine. Oct. 30, 1960.

18. Ohio Year Book. Vol. 14. World Publishing Co., Cleveland, Ohio. 1961.

19. Dictionary of American History. Vol. 5. Scribners.

20. Newspaper clipping from my file with date line: "Special to the Express-Columbus, Jan. 15." News story about the election of Squirrel Hunter officers and plans for a June meeting to discuss legislation desired to give them a pension and other privileges. (I have been unable to identify either the name of the town in which the paper was located or the year.)

\section{Personnel Changes}

It is with regret that we announce the resignation of Fleming Fraker, Jr. from the ANNALs staff. Mr. Fraker served as editor of the ANNALS for just under four years and the loss of his services to this publication will be most difficult to remedy. We wish the best of good fortune for the future of this talented young man.

The position of Museum Director, vacant since its previous occupant Jack W. Musgrove assumed the responsibilities of Curator, has recently been filled by Richard Boyt. 
Copyright of Annals of Iowa is the property of State of Iowa, by \& through the State Historical Society of Iowa and its content may not be copied or emailed to multiple sites or posted to a listserv without the copyright holder's express written permission. However, users may print, download, or email articles for individual use. 